\title{
Quality of Broilers Fed Diets Containing Dry Distillery Grains
}

\author{
Jean Kaique Valentim (Corresponding author) \\ Department of Animal Science, Universidade Federal da Grande Dourados (UFGD), MS, \\ Dourados, Brazil. E-mail: kaique.tim@hotmail.com
}

\section{Heder José D'Ávila Lima}

Department of Animal Science, Universidade Federal dos Vales do Jequitinhonha e Mucuri (UFVJM), Diamantina, MG, Brazil

Tatiana Marques Bittencourt

Departamento of Animal Husbandry and Rural Extension, Universidade Federal de Mato Grosso (UFMT), Cuiabá, MT, Brazil

Jonatan Mikhail Del Solar Velarde

Department of Animal Science, Universidade Federal de Sergipe (UFS), SE, São Cristovão, Brazil

Luciana Kimie Savay-da-Silva

Department of Food and Nutrition, Faculty of Nutrition, Universidade Federal de Mato Grosso (UFMT), Cuiabá, MT, Brazil

Nayara Emanoelle Matos e Silva, Diego Pierrotti Procópio

Departamento of Animal Husbandry and Rural Extension, Universidade Federal de Mato Grosso (UFMT), Cuiabá, MT, Brazil

Maria Fernanda de Castro Burbarelli, Rodrigo Garófallo Garcia, Janaína Palermo Mendes

Department of Animal Science, Universidade Federal da Grande Dourados (UFGD), MS, Dourados, Brazil

Received: Dec. 23, 2019 Accepted: Feb. 11, $2020 \quad$ Published: Feb. 25, 2020 


\begin{abstract}
The present study aimed to evaluate carcass, cut yields and gastrointestinal tract biometry, the meat quality and body lesions of broiler chicken fed with four levels of corn distillers dried grain with soluble in experimental diets. A total of 700 day-old mixed flock Cobb 500 broiler chicks were distributed in a completely randomized design with five treatments, seven replicates by treatment with 20 birds each. The experimental diets were controlled with crescent inclusion levels of DDGS (4, 8, 12 and 16\%). At 35 days of age 2 broilers from each lot was selected, weighted and identified with medium weight from the experimental unit for slaughtering and evaluation of cuts yield, carcass and gastrointestinal biometry. To evaluate hock lesions and broiler meat quality. Quadratic effect was observed in reference to the weight of the carcass and chest can be included the levels up to 11.29 percent and 6.16 percent respectively. For the other variables of income of casting, edible organs and not edible and there was no significant effect on gastrointestinal biometrics, only for the total size of the gastrointestinal tract there was quadratic effect being the level of $4.25 \%$ indicated for increased size of the organs. For all welfare and meat quality variables evaluated, there was no difference between the DDGS levels used in broiler diets and control diet. These findings means that the addition of up to $16 \%$ DDGS in diets can be an alternative to feed chicken without inducing body lesions neither altering broiler meat quality.
\end{abstract}

Keywords: carcass yields, water retention capacity, chicken lesions, pododermatitis

\title{
1. Introduction
}

Current profile of animal protein consumers has changed over the last years, they are looking for quality instead of price which supported industry and research activities to assign more value for animal welfare (Oliveira, 2015). Poultry environment is influenced by a range of factors including nutritional aspects, which may affect poultry performance and welfare. Thus, replacement of conventional food by alternative ones, must not compromise animal's welfare, yield and final product quality.

According to Bilgili et al. (2006), the occurrence of broiler carcass lesions has been associated with diets and poor litter quality. It is common to find high incidence of chest calluses, hock lesions and pododermatitis in warehouses that have compacted litter. Those findings may contribute to decreasing broiler growth rate leading economic losses mainly due meat condemnation at slaughter (Saraiva et al., 2016). The carcass quality and physicochemical aspects are related to the sensory characteristics of poultry meat, hereby can be considered important factors in consumer choices of animal protein (Font-i-Furnols \& Guerrero, 2014).

Corn distillers dried grains with soluble (DDGS) is one of ethanol industry co-products, which is generated from after corn starch fermentation by yeasts and enzymes (Cuevas et al., 2012). DDGS can be considered source of proteins, amino acids, energy, phosphorus and many other nutrients. However, this ingredient has high amount of non-starch polysaccharides, resulting in 
lower digestibility of nutrients for broiler chicken. Different fiber sources could increase or decrease water consumption and consequently influences litter humidity.

Thus, consumption of high fiber content ingredients as DDGS may influence litter quality and therefore bring about changes in meat quality and economic losses in the carcass production. Furthermore, high humidity in poultry litter increases incidence of body lesions causing pain and affecting welfare (Benincasa, 2017). Therefore, this study aimed evaluate carcass yield, meat quality and characterize body lesions of broiler chicken fed with experimental diets including five different DDGS inclusion levels.

\section{Material and Methods}

The trial was carried out in Animal Science and Agronomy Farm of Federal University of Mato Grosso - Cuiabá - Brazil broiler experimental facilities and was approved by the ethics committee on animal use (CEUA) of the same university, under the registry number: 23108.227104 / 2017 - 13. A total of 700 - day - old male and female Cobb 500 broiler chicks were distributed in 35 pens in a completely randomized design, each experimental unit had 20 birds, 10 male and 10 female. Five experimental diets were utilized with four levels of DDGS inclusion $(4,8,12$ and $16 \%)$ and a control $(0 \%)$, each diet was offered to seven pens by treatment. Diets were isonutritives, based on corn and soybean meal and formulated according nutritional recommendations of the lineage $(\mathrm{COBB}, 2001)$ (Table 1). Nutritional composition of ingredients were based on recommendations of Wiltafsky et al. (2010) and amino-acid content was based on Rostagno et al. (2005). Feeding program was divided into two different phases, during 1 to 7 days and 8 to 35 .

Table 1. Percentage composition of the experimental rations of broilers from 1 to 7,8 to 35

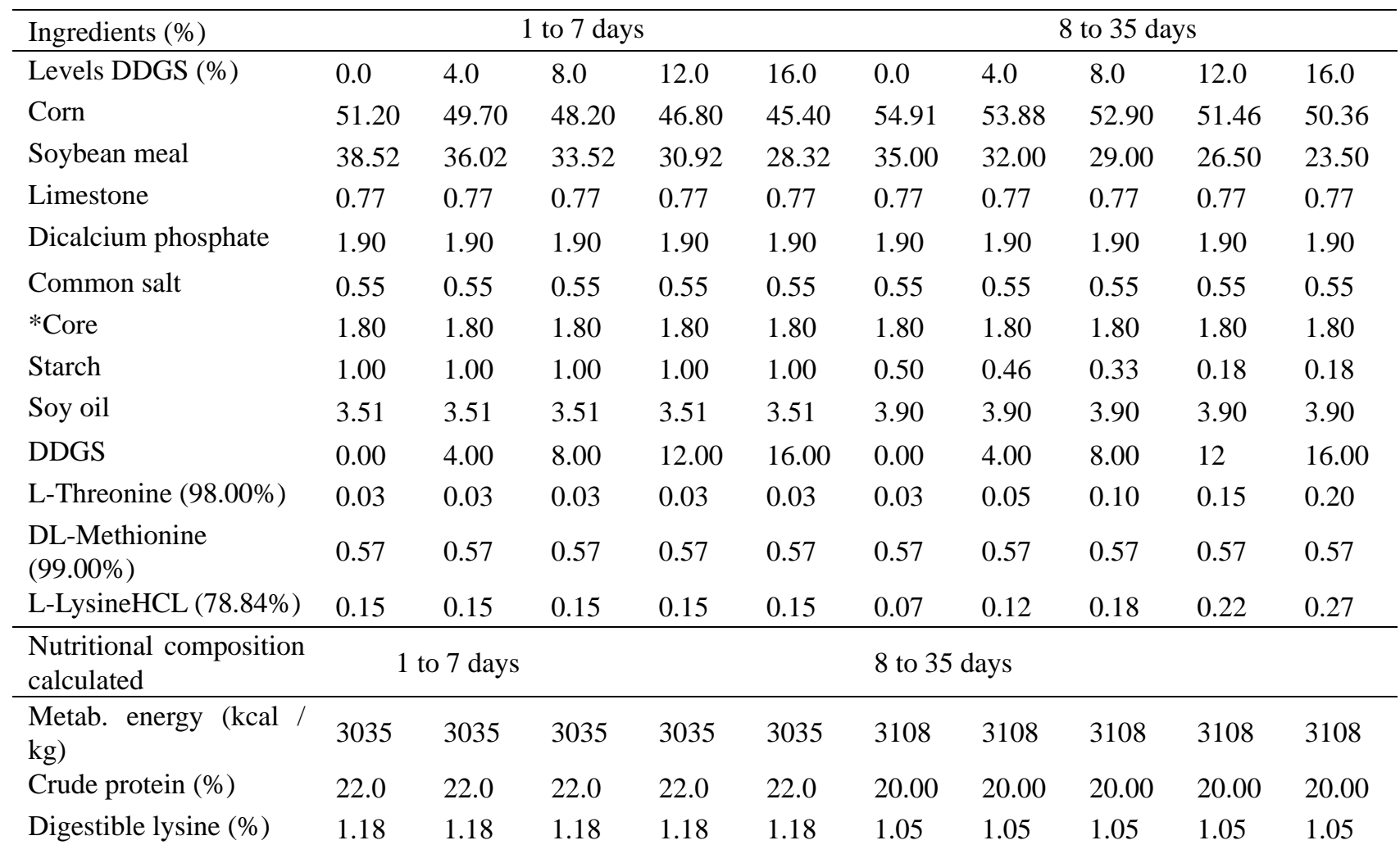




\begin{tabular}{|c|c|c|c|c|c|c|c|c|c|c|}
\hline $\begin{array}{l}\text { Digestible met.+cystine } \\
(\%)\end{array}$ & 0.88 & 0.88 & 0.88 & 0.88 & 0.88 & 0.80 & 0.80 & 0.80 & 0.80 & 0.80 \\
\hline $\begin{array}{l}\text { Tryptophan digestible } \\
(\%)\end{array}$ & 0.18 & 0.18 & 0.18 & 0.18 & 0.18 & 0.17 & 0.17 & 0.17 & 0.17 & 0.17 \\
\hline $\begin{array}{l}\text { Digestible threonine } \\
(\%)\end{array}$ & 0.77 & 0.77 & 0.77 & 0.77 & 0.77 & 0.69 & 0.69 & 0.69 & 0.69 & 0.69 \\
\hline Calcium $(\%)$ & 0.90 & 0.90 & 0.90 & 0.90 & 0.90 & 0.84 & 0.84 & 0.84 & 0.84 & 0.84 \\
\hline Match available (\%) & 0.45 & 0.45 & 0.45 & 0.45 & 0.45 & 0.42 & 0.42 & 0.42 & 0.42 & 0.42 \\
\hline Sodium $(\%)$ & 0.23 & 0.23 & 0.23 & 0.23 & 0.23 & 0.23 & 0.23 & 0.23 & 0.23 & 0.23 \\
\hline Crude fiber $(\%)$ & 2.96 & 3.09 & 3.21 & 3.33 & 3.46 & 2.84 & 3,13 & 3.41 & 3.70 & 3.99 \\
\hline
\end{tabular}

$\uparrow$ EMAn values based on WPSA European Table of Energy Values for Poultry Feedstuffs (3rd edition, 1989). * Provides per kg of product: Calcium (max) 210g, Calcium (min) 170g, Phosphorus (min) 50g, Methionine (min) 22g, Vitamin A (min) 120000 IU, Vitamin D3 (min) 30000 IU, Vitamin E min) 400 IU, Thiamin (B1) (min) 35mg, Riboflavin (B2) (min) 130mg, Pyridoxine (B6) (min) 60mg, Vitamin B12 (min) 300mg, Vitamin K3 (Min) 1600mg, Zinc (min) 1380mg, Copper (min) 200mg, Colina (min) 400mg, Sodium (min) 26g, Manganese (min) (min) 160mg, Iron (min) 630mg, Iodine (min) 20mg, Selenium (min) 6mg, Fitase (min) 10000 FTU, Avilamycin 200mg, and Narasin + Navelbine 1000mg + 1000mg.

\subsection{Carcass Yield and Cuts Characteristics}

It was analyzed mixed lots of yield, evaluating carcass weight, breast weight, thigh, upper thigh, wings, edible viscera (heart, liver and gizzard) and non-edible viscera (proventriculus, duodenum, jejunum, ileum, cecum) and fat abdominal fat. The slaughtering and collect of samples was performed with chicken meat with 42 days of age. During this period the broilers remained without food ration for 8 hours, after that they were selected, weighted, and identified two broilers (a male and a female) from each lot with medium weight among the interval of $\pm 10 \%$ of the medium weight from the experimental unit, totalizing 70 slaughtered broilers.

Those broilers were euthanized by cervical dislocation and manually blooded through a cut in the jugular. After light scalding at the temperature of 56 degrees Celsius for 2 minutes, the broilers were taken to a rotate cylinder with plastic fingers to remove the feathers.

After the feathers removal, the broilers were once again weighted to obtain feathers weight; then, they were manually eviscerated and the carcass went to coolers for pre cooling, from where they left with 8 degrees Celsius. After the cooler the carcass remained in a stainless steel treadmill with roles so that the excess of water could be drained.

The carcass were weighted in a scale with capacity for $15 \mathrm{~kg}$ (Toledo, model: 9094) after the head, neck and feet were removed. For the calculus of yield, the commercial cuts were divided in breast, wings, thighs, upper thighs, edible viscera (liver, gizzard and heart); the non-edible viscera were divided in proventriculus, small intestine (duodenum, jejunum and ileum) and cecum. For the abdominal fat it was considered all the retroperitoneal fat, excluding what involves the gizzard. 
All the viscera and abdominal fat were weighted in semi analytical scale BL series, brand: shimadzu, BL $3200 \mathrm{H}$ model, capacity for $3200 \mathrm{~g}$. To scale the gizzard, all the food inside the organ was removed, keeping the keratin that involves it. The non-edible cuts (proventriculus, duodenum, jejunum, ileum and cecum) passed through a soft compression in order to eliminate the interior content, the clean tissue was weighted in a scale with precision of $0,5 \mathrm{~g}$ according to Reis et al. (2016).

The percent of yield of the main cuts, edible and non-edible viscera and abdominal fat were calculated by relation between medium weight of the representative cut of each repetition and the weight of the carcass according to the formula: Yield $\mathrm{x}=$ variable weight/Carcass weight* according to Reis et al. (2016).

\subsection{Gastrointestinal Tract Biometry}

Identification of the compartment of the gastrointestinal tract was given in the following way:

- Proventriculus: tissue that comes before the gizzard, easily identified after the exposition of the broilers viscera;

- Gizzard: Muscle tissue that comes before the beginning of the small intestine;

- Duodenum: part of the small intestine that goes from the end of the gizzard until the end of the duodenal handle that involves the pancreas;

- Jejunum: comprehends the end of the duodenal loop until the Meckel's diverticulum;

- Ileum: Begins at the Meckel's diverticulum, and prolongs itself until the ileum-cecum junction;

- Cecum: The dual cecum was identified adhered by crimps at the end of the ileum.

Each compartment mensuration was made after empting the intestinal content. The measurement was through the use of a $30 \mathrm{~cm}$ ruler, with $0,1 \mathrm{~mm}$ precision. To obtain values of relative length, the segment of each segment were divided by total length of the small intestine, and the results were multiplied by 100.

\subsection{Litter Quality Analysis}

Litter quality analysis was performed in all experimental units and measures were taken in three equidistant points of pens. The following classifications were adopted: 0 - completely dry and flaky, moves easily through the feet; 1 - Dry but not easy to move with foot; 2 - Leaves imprint of foot and will form a ball if compacted, but ball does not stay together well; 3 - Sticks to boots and sticks readly in a ball If compacted; 4 - Sticks to boots once the cap or compacted crust is broken.

\subsection{Characterization of Body Lesions}

All analyzes were performed by trained researchers in accordance with Welfare Quality, (2009). Plumage cleaning, hock lesion, pododermatitis indexes and chest callus were evaluated at 35 day old from 10 chickens from each pen. 
Plumage cleanliness index measurement was performed with scores ranging from 0 to 3 . Hock lesion and pododermatitis indexes were verified through scores ranging from 0 to 4 according to injury severity and the percentage of each score of all analysis were calculated. The chest callus was evaluated individually for presence or absence of callus equal to or greater than 0.5 $\mathrm{cm}^{2}$, according to Allain et al. (2009) methodology.

\subsection{Meat Quality}

For meat quality trial at 35 days all experimental chicken were fasted for eight hours and weighed. Two birds were selected from each pen with an average weight for slaughtering. Selected broiler were stunned by cervical dislocation and killed by cutting jugular vein, afterwards plucking and evisceration were carried out.

Chest muscle (Pectoralis major) of the carcasses were removed and placed in cold storage ( $4 \pm$ $1{ }^{\circ} \mathrm{C}$ ) for 24 hours. Measurements of $\mathrm{pH}$ at 24 hours after slaughter ( $\left.\mathrm{pH} 24 \mathrm{~h}\right)$, luminosity ( $\left.\mathrm{L}^{*}\right)$, $\mathrm{red} /$ green $\left(\mathrm{a}^{*}\right)$ and yellow/blue $\left(\mathrm{b}^{*}\right)$ contents; weight loss by thawing (WLT), by cooking (WLC), water retention capacity (WRC), drip loss (DL) and shear force (SF) were performed.

The $\mathrm{pH} 24 \mathrm{~h}$ determination was based on Zanetti et al. (2018) method using a potentiometer, Oakton pH 300 - 35618 series with a glass penetration electrode spiked in four different points of the chest muscle, two in the upper and two in the lower parts portion of the muscle.

For luminosity analysis $\left(\mathrm{L}^{*}\right)$, red/green $\left(\mathrm{a}^{*}\right)$ and yellow/blue $\left(\mathrm{b}^{*}\right)$ a portable colorimeter (Minolta Chroma Meter, Model CR - 400) was used reading CIE lab parameters with illuminating source D 65 , calibrated in standard white porcelain at $\mathrm{y}=93.7, \mathrm{x}=0.3160$ and $\mathrm{y}=$ 0.3323 . The final value was obtained from four readings in different points in the ventral region free of lesions.

To evaluate WLT, raw and frozen chicken breast muscle samples were weighed into a Shimadzu BL $3200 \mathrm{H}$ precision electronic scale and thawed in a refrigerator (Eletrolux ${ }^{\circledR} \mathrm{RDE}$ 30) at $4 \pm 1{ }^{\circ} \mathrm{C}$ for 24 hours, until sample internal temperature reached $10^{\circ} \mathrm{C}$ approximately. Thawed raw and frozen muscle samples were weighed and WLT was determined by the difference between sample initial and final weights, according to Kuss et al. (2005) methodology.

For WLC determination one half of chicken breast was weighted on precision electronic scale (Marconi ${ }^{\circledR}$ model AS 1000), packed in plastic bag, boiled in water bath (Thermomix BM $18 \mathrm{BU}$ - Braun Biotech International) $80^{\circ} \mathrm{C}$ for 60 minutes, cooled for 50 minutes $\left(45 \pm 2{ }^{\circ} \mathrm{C}\right)$ and weighted (Froning \& Uijttenboogaart, 1988).

Samples boiled for WLC were cut in pieces of $1 \mathrm{~cm}$ x $1 \mathrm{~cm} \times 2 \mathrm{~cm}$; height, width and length, respectively, and reached room temperature for evaluation of meat tenderness $(\mathrm{kg}-\mathrm{f})$, in which a blade ruptures the sample muscle fibers oriented perpendicularly to texturometer blade.

For WRC analysis, approximately $2.0 \mathrm{~g}$, of chicken breast sample were weighted and placed between two filter papers and acrylic plates, which received a pressure of $10.0 \mathrm{~kg}$ for 5 minutes. Afterwards, weighed again to estimate amount lost water in relation to initial weight (Hamm \& Deatherage, 1960). 
For DL assay, approximately $200 \mathrm{~g}$ of breast meat were wrapped in a reticulated plastic bag, suspended inside other plastic bag, and kept in cold storage $\left(2 \pm 1^{\circ} \mathrm{C}\right)$ for 48 hours. Samples were removed from cold storage; surface moisture was dried with absorbent paper and weighted (Van Laack et al., 2000). Shear force was measured with Stable Micro Systems TAXT 2 Plus texturometer equipped with Warner Bratzler V set probe blades, calibrated to the standard $5 \mathrm{~kg}$ weight; device parameters for descendent and cutting velocity were set at 200 $\mathrm{mm}$ per minute. The maximum positive peaks were obtained using Exponent Lite version 5.1, Stable micro systems, software.

\subsection{Statistical Analyzes}

Litter quality and body lesion scoring data was studied assuming normal distribution and submitted to analysis of variance at $5 \%$ of probability using the SAS $®$. When DDGS inclusion was significant, contrasts were tested by Dunnett's test at $5 \%$ probability comparing control treatment with inclusions of DDGS.

\section{Results and Discussion}

The average income of casting variables, yield of edible and non-edible offal of chickens to 35 days fed with diets containing levels of DDGS are presented in table 2.

Table 2. Weight and percentage of carcass, breast, thigh, drumstick, heart, gizzard, liver, spleen and abdominal fat of chickens mix to 35 days fed with diets containing levels of DDGS

\begin{tabular}{|c|c|c|c|c|c|c|c|}
\hline \multirow[b]{2}{*}{ Parameters } & \multicolumn{5}{|c|}{ Corn DDGS levels (\%) } & \multirow[b]{2}{*}{$\mathrm{CV}(\%)$} & \multirow[b]{2}{*}{ P-value } \\
\hline & 0 & 4 & 8 & 12 & 16 & & \\
\hline Carcass weight $(\mathrm{g})^{2}$ & 1397.14 & 1407.14 & 1319.29 & $1275.36^{*}$ & $1204.29 *$ & 5.77 & 0.0004 \\
\hline Breast weight $(\mathrm{g})^{2}$ & 431.43 & 442.86 & 396.43 & $381.79 *$ & $356.071 *$ & 9.27 & 0.0016 \\
\hline Thigh weight (g) & 197.86 & 193.57 & 191.79 & 188.93 & 173.21 & 8.92 & 0.1162 \\
\hline Weight drumstick (g) & 180.717 & 168.21 & 160.71 & 165.00 & 166.79 & 10.74 & 0.8708 \\
\hline Wing weight $(\mathrm{g})$ & 136.79 & 136.07 & 132.143 & 128.93 & 122.5 & 6.99 & 0.0617 \\
\hline$\%$ of housing & 80.7855 & 79.7882 & 79.2678 & 79.2868 & 78.3858 & 1.83 & 0.3518 \\
\hline$\%$ Breast & 34.5685 & 35.6673 & 33.5042 & 33.9216 & 33.7528 & 6.31 & 0.2504 \\
\hline$\%$ Thigh & 15.9557 & 15.6235 & 16.1873 & 16.859 & 16.3975 & 7.72 & 0.3477 \\
\hline$\%$ Weight & 14.5139 & 13.5868 & 13.6017 & 14.7668 & 15.7983 & 10.9 & 0.435 \\
\hline$\%$ Wing & 11.0131 & 11.0076 & 11.1668 & 11.4893 & 11.6057 & 6.24 & 0.3718 \\
\hline Heart weight (g) & 9.1407 & 9.945 & 9.2957 & 8.6286 & 8.68 & 10.95 & 0.0757 \\
\hline Liver weight (g) & 36.8443 & 37.1864 & 36.11 & 33.2771 & 33.1886 & 10.97 & 0.1479 \\
\hline Gizzard weight (g) & 30.87 & 31.6271 & 31.18 & 32.5286 & 29.535 & 11.91 & 0.5097 \\
\hline Abdominal fat $(\mathrm{g})$ & 22.124 & 16.862 & 14.827 & 14.795 & 13.848 & 14.66 & 0.4974 \\
\hline$\%$ Heart & 0.5288 & 0.5631 & 0.5584 & 0.537 & 0.5647 & 11.59 & 0.5695 \\
\hline$\%$ Liver & 2.1306 & 2.102 & 2.1765 & 2.065 & 2.1648 & 9.33 & 0.7534 \\
\hline$\%$ Gizzard & 1.7867 & 1.7931 & 1.8668 & 1.7405 & 1.7485 & 10.71 & 0.2287 \\
\hline$\%$ abdominal fat & 1.2871 & 0.9539 & 0.8935 & 0.928 & 0.9029 & 15.15 & 0.9504 \\
\hline
\end{tabular}

1 linear effect $(\mathrm{P}<0.05)$; ${ }^{2}$ quadratic effect $(\mathrm{P}<0.05)$; * Significant at 5\% probability by Dunnett test; Regression equation: carcass weight: $1576.05-94.62 \mathrm{x}+4.19 \mathrm{x}^{2} ; \mathrm{R}^{2}: 98.83 \%$. Breast: $547.50-63.75 \mathrm{x}+5.17 \mathrm{x}^{2} ; \mathrm{R}^{2}: 97.69 \%$.

Quadratic effect was observed $(\mathrm{p}<0.005)$ to the weight of the carcass and weight chest, and may be included the levels up 11.29 percent and 6.16 percent respectively. With respect to other variables, no difference was observed between the levels used. The test of Dunnet ( $\mathrm{p}$ 0.005 ) shows that there was a decline in the weight of the carcass and chest at the level of $12 \%$ 
and $16 \%$ in comparison to the control treatment $(0 \%)$. Thus, the addition of DDGS in these levels can cause a reduction in muscle deposition in housing and in the chest.

The chest represents about $50 \%$ of the total protein from the carcass, so that cut is much more sensitive to variations in diets, especially in relation to amino acids, when compared to other commercial cuts. Sariozkan et al. (2015) evaluating the effects of dietary supplementation of DDGS on broiler performance concludes that there was a decrease in yield of carcass, breast and drumstick with the addition of $30 \%$ of this co-product. Rochell (2018) reported that 10 to $15 \%$ of DDGS as source of protein could be included without negative effects on broiler carcass yield parameters. Kaya et al. (2013) using DDGS in diets of broilers up to $15 \%$, did not find differences to the chest of broilers.

The main justification presented in the literature as to the risks of the use of DDGS is with respect to excess dietary fiber which can increase the number of intestinal Goblet cells, which are the main producers of mucus, to facilitate the passage of food in the digestive tract, and decreasing the intestinal $\mathrm{pH}$ and the size of the villi, caused reduction in the absorption of nutrients and consequently less muscle protein deposition.

With respect to the biometrics of the gastrointestinal tract quadratic effect was observed for the total size of the gastrointestinal tract (TGI) (Table 3), being the level of $4.25 \%$ indicated for better development.

Table 3. Length, weight and percentage of proventriculus, spleen, duodenum, jejunum, ileum, heart, gizzard, liver, spleen, abdominal fat of chickens to mixed 35 days fed with diets containing levels of DDGS

\begin{tabular}{|c|c|c|c|c|c|c|c|}
\hline & & Corr & DDGS le & ls $(\%)$ & & & \\
\hline Parameters & 0 & 4 & 8 & 12 & 16 & $\mathrm{CV}(\%)$ & P-value \\
\hline Proventriculus weight (g) & 8.4321 & 8.3657 & 8.0064 & 8.2936 & 8.0836 & 16.32 & 0.9516 \\
\hline Spleen weight (g) & 1.5971 & 1.7779 & 1.5814 & 1.5571 & 1.495 & 17.51 & 0.2354 \\
\hline Duodenal weight (g) & 16.4107 & 15.7307 & 14.574 & 14.133 & 14.0571 & 14.14 & 0.4083 \\
\hline Middle weight (g) & 18.405 & 19.3114 & 16.710 & 17.712 & 16.9529 & 14.03 & 0.2258 \\
\hline Small intestine weight $(\mathrm{g})$ & 18.4136 & 17.63 & 17.473 & 16.917 & 14.8543 & 17.89 & 0.2984 \\
\hline Weight cecum $(\mathrm{g})$ & 15.8957 & 14.1043 & 14.822 & 14.983 & 15.5843 & 13.61 & 0.6053 \\
\hline$\%$ proventriculus & 0.4879 & 0.4761 & 0.4827 & 0.5149 & 0.5262 & 15.77 & 0.4266 \\
\hline$\%$ Weight duodenum & 0.9494 & 0.8907 & 0.8783 & 0.882 & 0.9158 & 15.74 & 0.9744 \\
\hline \% Weight jejunum & 1.0713 & 1.0934 & 1.0062 & 1.0974 & 1.1057 & 12.26 & 0.574 \\
\hline \% Weight ileum & 1.0639 & 0.997 & 1.0515 & 1.0543 & 0.973 & 18.76 & 0.8699 \\
\hline$\%$ Weight cecum & 0.9272 & 0.809 & 0.8929 & 0.9291 & 1.0117 & 13.23 & 0.213 \\
\hline Duodenum (cm) & 28.221 & 28.485 & 26.700 & 26.328 & 26.614 & 8.00 & 0.8361 \\
\hline Jejunum (cm) & 71.692 & 77.357 & 71.292 & 70.542 & 71.914 & 7.33 & 0.0961 \\
\hline Ileum (cm) & 76.821 & 81.585 & 73.857 & 72.657 & 70.814 & 11.44 & 0.1189 \\
\hline TGI total $(\mathrm{cm})^{2}$ & 176.74 & $187.43^{*}$ & 171.85 & 169.53 & 169.34 & 7.25 & 0.0381 \\
\hline$\%$ duodenum $(\mathrm{cm})$ & 16.139 & 15.220 & 15.419 & 15.566 & 15.838 & 7.3 & 0.9785 \\
\hline \% jejunum $(\mathrm{cm})$ & 40.292 & 41.300 & 41.858 & 41.472 & 42.588 & 8.04 & 0.8938 \\
\hline$\%$ ileum $(\mathrm{cm})$ & 43.568 & 43.479 & 42.721 & 42.961 & 41.573 & 6.51 & 0.6275 \\
\hline
\end{tabular}

1 linear effect $(\mathrm{P}<0.05)$; ${ }^{2}$ quadratic effect $(\mathrm{P}<0.05)$; $*$ Significant at $5 \%$ probability by Dunnett test; Regression equation: Total TGI: $236.64-32.57 x+3.84 x^{2} . R^{2}: 97.21 \%$. 
The non-starchy polysaccharides can interfere with the animal's performance, depending on their concentration, being resistant to hydrolysis in the digestive tract (Brito et al., 2008). These compounds cannot be degraded by endogenous enzymes, affecting the digestibility of nutrients, decrease the energy of the diet and modify the length of stay of food in the digestive tract (Pinheiro et al., 2017).

The increased viscosity of digest nutrients as fats, starch and proteins, become less accessible and available endogenous enzymes, this viscosity decreases the rate of diffusion of substrates and digestive enzymes and prevents your int those on the surface of the intestinal mucosa (Miranda et al., 2017), at the initial stage of animal life where your enzyme haven't this apparatus formed interference may reduce the development of TGI, which explains the reduction of your size with additions above $4 \%$ of DDGS.

The DDGS inclusion levels did not affect $(\mathrm{P}>0.05)$ body lesions evaluated in whole experimental population (Table 4).

Table 4. Broiler body lesions fed with diets including four DDGS levels at 35 days of age

\begin{tabular}{lccccccc}
\hline & \multicolumn{7}{c}{ DDGS Inclussion levels $(\%)$} \\
\cline { 2 - 6 } Parameters & 0 & 4 & 8 & 12 & 16 & CV (\%) & P-value \\
\hline Plumage cleaning index & 1.571 & 1.571 & 1.428 & 1.714 & 1.428 & 5.76 & 0.898 \\
Hock lesion index & 1.230 & 1.030 & 1.285 & 0.857 & 1.000 & 8.32 & 0.881 \\
Pododermatitis & 1.714 & 1.100 & 1.571 & 0.857 & 1.285 & 3.45 & 0.455 \\
Chest callus & 2.000 & 2.000 & 1.857 & 2.000 & 2.000 & 8.67 & 0.677 \\
\hline Quality of bed & 1.928 & 2.145 & 2.178 & 2.345 & 2.234 & 7.98 & 0.645 \\
\hline
\end{tabular}

$\mathrm{CV}$ : coefficient of variation

Schone et al. (2017) characterized DDGS as an ingredient with high amounts of nutrients and fiber, about $72.95 \%$ of NDF which is associated to production losses in poultry. All lesions scores ranged between zero and two showing that birds fed with DDGS didn't have significant problems and also, values obtained in the present study are considered normal for poultry industry.

In other hand, Boling \& Firman (1997) noted that diets with high potassium as corn soybean meal based, may lead to electrolyte diet imbalance, resulting in higher water consumption, thus causing wet problems to litter and, consequently pododermatitis, which was not significantly observed in this study. Higher quality of litter is generally correlated with bird plumage cleaning aspect (Federici et al., 2016). According to Reis et al. (2016) chickens classified score three are unacceptable, due to hygiene aspects.

The present study showed scoring values between 1.428 and 1.714, which demonstrates low severity injuries regarding high quality meat. Pododermatitis and hock lesions are excellent indicators chicken litter quality (Youssef et al., 2010) which is affected in a multifactorial way, associated to nutritional, genetic, environmental or management disturbances. Additionally, leg lesions are associated to high density, diets and management issues related to litter quality, as type of material and moisture.

Diets used in the present study were isonutritive, and only showed difference in crude fiber 
content, this was not sufficient to provide differences among the variables studied. Higher protein contents and metabolic disorders in diets influences negatively on litter quality (excretion of nitrogen, high levels of ammonia and wet poultry litter) and consequently carcasses condemnation (Alves et al., 2013; Whitehead \& Bannister, 1981).

Magalhães et al. (2015) evaluating the nutritional value of DDGS, founded high apparent digestibility coefficient for protein, low dry matter digestibility due to the high fiber content, which results in greater nutrients excretion, litter quality decreasing and consequently increasing body injury rates, differently from the findings of the present study. Although, deficiency or excess of certain essential nutrients play important role in the development of several legs problems in poultry, hence, many disorders occur not in nutritional order (Venturini \& Sarcinelli, 2007).

There was no significant effect of inclusion of DDGS in broiler diets in meat quality parameters (Table 5).

Table 5. Broiler meat quality at day 35 fed with diets containing four DDGS inclusion levels

\begin{tabular}{lccccccc}
\hline & \multicolumn{7}{c}{ DDGS levels (\%) } \\
\hline Traits & 0 & 4 & 8 & 12 & 16 & CV (\%) & P-valor \\
\hline Weight loss on cooking (\%) & 16.78 & 15.48 & 17.91 & 18.14 & 19.12 & 5.21 & 0.350 \\
\hline Color L & 54.21 & 54.63 & 53.48 & 56.23 & 54.05 & 4.31 & 0.649 \\
\hline Color a* & 3.18 & 3.23 & 3.18 & 3.23 & 3.06 & 7.56 & 0.839 \\
\hline Color b* & 5.18 & 5.60 & 5.12 & 5.73 & 5.85 & 8.54 & 0.391 \\
\hline Drip loss (\%) & 4.46 & 5.29 & 4.90 & 4.81 & 5.021 & 13.45 & 0.862 \\
\hline Loss on thawing (\%) & 8.24 & 8.53 & 8.66 & 9.17 & 9.52 & 15.76 & 0.885 \\
\hline pH 24h & 5.95 & 6.17 & 6.05 & 5.81 & 5.91 & 7.21 & 0.074 \\
\hline Water retention capacity (\%) & 35.54 & 36.91 & 34.02 & 36.87 & 37.77 & 5.31 & 0.405 \\
\hline Shear force (kgf) & 41.49 & 42.94 & 40.17 & 44.88 & 42.47 & 16.76 & 0.930 \\
\hline
\end{tabular}

$\mathrm{CV}$ : coefficient of variation.

Meat quality proprieties are directly related to water retention capacity (Schilling et al., 2010), which influences palatability and shelf life (Francisco et al., 2007). In the present study inclusion of DDGS demonstrated be practicable up to $16 \%$ without impairing quality, all quality variables remained unchanged. Luminosity parameters $\left(L^{*} . a^{*}\right.$ and $\left.b^{*}\right)$ showed similar values with DDGS inclusion in broiler diets diets.

Color may be considered one of the most important parameters quality for meat products, consumers first analyze the color of the product, and if it is not as expected the product may be reject (Jiang et al., 2014). Also, luminosity presents high correlation with meat pallor, which may be related with PSE Meat (Pale, Soft and Exsudative). This meat condition is characterized as a combination of $\mathrm{pH}$ (below 5.8) and color ( $\mathrm{L}^{*}$ above 54.0).

Comparing results of the present study with standards of PSE meat is possible assert that all DDGS inclusion samples were not affected by this condition.

Results founded in the present study corroborates with Corzo et al. (2009) which included 8\% and $15 \%$ of DDGS in broiler diets and were not observed differences in breast and thigh meat, 
color, $\mathrm{pH}$, cooking loss, drip loss and shear force values. Considering the $\mathrm{pH}$ of the present study samples, all levels of DDGS inclusion maintained $\mathrm{pH}$ between 6.3 and 6.8, considered normal values for poultry meat 15 hours before slaughtering (Battula et al., 2008).

The $\mathrm{pH}$ influences coloring, light reflectance, alter meat physical structure, water retention capacity, softness, weight loss by cooking, succulence and microbiological stability (Contreras-Castillo et al., 2008), which demonstrates the importance of maintenance of this parameter between standards. According Mir et al. (2018) the inclusion of DDGS levels increases loss of water by drip and lipid peroxidation, while reducing the antioxidant capacity of chicken meat.

Meat texture is related to the amount of intramuscular water, the higher is water contents inside the muscle, the greater meat tenderness. Water contents inside muscle may be influenced by nutritional content of the diets, to the management during the production, in the pre-and post-slaughter periods. In the present study diets offered to broiler showed positive influences in water retention and consequently tenderness (Zhang et al., 2013). DDGS in diets may be considered an alternative ingredient in broiler diets up to $16 \%$ inclusion, due to the absence of disturbances in meat quality and occurrence of body lesions.

\section{References}

Allain, V., Mirabito, L., Arnould, C., Colas, M., Le Bouquin, S., Lupo, C., \& Michel, V. (2009). Skin lesions in broiler chickens measured at the slaughterhouse: Relationships between lesions and between their prevalence and rearing factors. British Poultry Science, 50(4), 407-417. https://doi.org/10.1080/00071660903110901

Alves, M. C. F., Almeida Paz, I. C. L., Caldara, F. R., Nääs, I. A., Garcia, R. G., Seno, L. O., ... Amadori, M. S. (2013). Equilibrium Condition and Locomotion Problems in Broilers. Revista Brasileira de Engenharia de Biossistemas, $7(1), \quad 35$. https://doi.org/10.18011/bioeng2013v7n1p35-44

Battula, V., Schilling, M. W., Vizzier-Thaxton, Y., Behrends, J. M., Williams, J. B., \& Schmidt, T. B. (2008). The Effects of Low-Atmosphere Stunning and Deboning Time on Broiler Breast Meat Quality. Poultry Science, 87(6), 1202-1210. https://doi.org/10.3382/ps.2007-00454

Benincasa, N. C. (2017). Characterization of broiler breeding system in commercial negative pressure aviaries, pre-slaughter operations and meat quality [Text, Universidade de São Paulo]. https://doi.org/10.11606/D.11.2018.tde-21032018-154704

Bilgili, S. F., Alley, M. A., Hess, J. B., \& Nagaraj, M. (2006). Influence of Age and Sex on Footpad Quality and Yield in Broiler Chickens Reared on Low and High Density Diets. Journal of Applied Poultry Research, 15(3), 433-441. https://doi.org/10.1093/japr/15.3.433

Boling, S., \& Firman, J. (1997). Rendered By-products as Soybean Meal replacement in turkey rations. Journal of Applied Poultry Research, 6(2), 210-215. https://doi.org/10.1093/japr/6.2.210 
Brito, M. S. de, Oliveira, C. F. S. de, Silva, T. R. G. da, Lima, R. B. de, Morais, S. N., \& Silva, J. H. V. da. (2008). Polysaccharides not amylaceous in the monogastric nutrition revision. Acta Veterinaria Brasilica, 2(4), 111-117. https://doi.org/10.21708/avb.2008.2.4.917

COBB. (2001). Manual de manejo de frangos Cobb 500: Guia de manejo.

Contreras-Castillo, C. J., Brossi, C., Previero, T. C., \& Demattê, L. C. (2008). Performance and carcass quality of broilers supplemented with antibiotics or probiotics. Brazilian Journal of Poultry Science, 10(4), 227-232. https://doi.org/10.1590/S1516-635X2008000400006

Corzo, A., Schilling, M. W., Loar, R. E., Jackson, V., Kin, S., \& Radhakrishnan, V. (2009). The effects of feeding distillers dried grains with solubles on broiler meat quality. Poultry Science, 88(2), 432-439. https://doi.org/10.3382/ps.2008-00406

Cuevas, A. C., Carrillo, C. A. E., Elizalde, G. S., Iriarte, J. M., Roa, M. O., \& González, E. Á. (2012). Use of distillers dried grains with soluble (DDGS) on sorghum-soybean meal diets for broilers and laying hens. Revista Mexicana de Ciencias Pecuarias, 3(3), 331-341.

Federici, J. F., Vanderhasselt, R., Sans, E. C. O., Tuyttens, F. a. M., Souza, A. P. O., Molento, C. F. M., ... Molento, C. F. M. (2016). Assessment of Broiler Chicken Welfare in Southern Brazil. Brazilian Journal of Poultry Science, 18(1), 133-140. https://doi.org/10.1590/18069061-2015-0022

Font-i-Furnols, M., \& Guerrero, L. (2014). Consumer preference, behavior and perception about meat and meat products: An overview. Meat Science, 98(3), 361-371. https://doi.org/10.1016/j.meatsci.2014.06.025

Francisco, D. C., Nascimento, V. P. do, Loguercio, A. P., \& Camargo, L. (2007). Caracterização do consumidor de carne de frango da cidade de Porto Alegre. Ciência Rural, 37(1), 253-258. https://doi.org/10.1590/S0103-84782007000100041

Froning, G. W., \& Uijttenboogaart, T. G. (1988). Effect of Post-Mortem Electrical Stimulation on Color, Texture, $\mathrm{pH}$, and Cooking Losses of Hot and Cold Deboned Chicken Broiler Breast Meat. Poultry Science, 67(11), 1536-1544. https://doi.org/10.3382/ps.0671536

Hamm, R., \& Deatherage, F. E. (1960). Changes in Hydration, Solubility and Charges of Muscle Proteins During Heating of Meata. Journal of Food Science, 25(5), 587-610. https://doi.org/10.1111/j.1365-2621.1960.tb00004.x

Jiang, W., Nie, S., Qu, Z., Bi, C., \& Shan, A. (2014). The effects of conjugated linoleic acid on growth performance, carcass traits, meat quality, antioxidant capacity, and fatty acid composition of broilers fed corn dried distillers grains with solubles. Poultry Science, 93(5), 1202-1210. https://doi.org/10.3382/ps.2013-03683

Kaya, H., Kaya, A., Celebi, S., \& Macit, M. (2013). Effects of Dietary Supplementation of Essential Oils and Vitamin E on Performance, Egg Quality and Escherichia Coli Count in Excreta. Indian Journal of Animal Research, 47(6), 6.

Kuss, F., Restle, J., Brondani, I. L., Alves Filho, D. C., Perottoni, J., Missio, R. L., \& Amaral, G. A. do. (2005). Carcass Physical Composition and Meat Quality of Cull Cows of Different 
GeneticGroups Feedlot Finished and Slaughtered with Distinct Weights. Revista Brasileira de Zootecnia, 34(4), 1285-1296. https://doi.org/10.1590/S1516-35982005000400025

Magalhães, R., Coutinho, F., Pousão-Ferreira, P., Aires, T., Oliva-Teles, A., \& Peres, H. (2015). Corn distiller's dried grains with solubles: Apparent digestibility and digestive enzymes activities in European seabass (Dicentrarchus labrax) and meagre (Argyrosomus regius). Aquaculture, 443, 90-97. https://doi.org/10.1016/j.aquaculture.2015.03.016

Mir, N. A., Tyagi, P. K., Biswas, A. K., Tyagi, P. K., Mandal, A. B., Kumar, F., Sharma, D., Biswas, A., \& Verma, A. K. (2018). Inclusion of Flaxseed, Broken Rice, and Distillers Dried Grains with Solubles (DDGS) in Broiler Chicken Ration Alters the Fatty Acid Profile, Oxidative Stability, and Other Functional Properties of Meat. European Journal of Lipid Science and Technology, 120(6), 1700470. https://doi.org/10.1002/ejlt.201700470

Miranda, L. M. B. de, Goulart, C. de C., Leite, S. C. B., Batista, A. S. M., Lima, R. C., Miranda, L. M. B. de, Goulart, C. de C., Leite, S. C. B., Batista, A. S. M., \& Lima, R. C. (2017). Farelo de algodão em dietas com ou sem suplementação de enzimas para frango de corter Revista Ciência Agronômica, 48(4), 690-699. https://doi.org/10.5935/1806-6690.20170080

Oliveira, A. P. de. (2015). Caracterização do consumidor de carne de frango em Júlio Borges-PI. Revista Científica de Produção Animal, 17(2), 129-141. https://doi.org/10.15528/2176-4158/rcpa.v17n2p129-141

Pinheiro, S. R. F., Vieira, D. J., Moreira, D. R. F., Barbosa, K. A., Ferreira, H. J., \& Bonafé, C. M. (2017). Farelo de crambe (Crambe abyssinica) em rações para frangos de corte. Archivos de Zootecnia, 66(256), 557-561. https://doi.org/10.21071/az.v66i256.2772

Reis, T. L., Calixto, L. F. L., Lima, M. F. de, Lemos, M. J. de, Alves, O. dos S., Cordido, K. A. A. T., ... Sousa, F. D. de R. (2016). Prebiótico e antibiótico como aditivos nas rações pré e pós-alojamento para frangos de corte. Revista Brasileira de Saúde e Produção Animal, 17(4), 719-728. https://doi.org/10.1590/s1519-99402016000400015

Rochell, S. (2018). Formulation of Broiler Chicken Feeds Using Distillers Dried Grains with Solubles. Fermentation, 4(3), 64. https://doi.org/10.3390/fermentation4030064

Rostagno, H. S., Albino, L. T., Donzele, J., Gomes, P., Oliveira, R. de, Lopes, D., ... Euclides, R. (2005). Tabelas brasileiras para aves e suínos: Composição de alimentos e exigências nutricionais (Vol. 2). UFV/DZO Viçosa.

Saraiva, S., Saraiva, C., \& Stilwell, G. (2016). Feather conditions and clinical scores as indicators of broilers welfare at the slaughterhouse. Research in Veterinary Science, 107, 75-79. https://doi.org/10.1016/j.rvsc.2016.05.005

Sariozkan, S., Konca, Y., Guclu, B. K., Kara, K., Ildiz, N., Kirkpinar, F., Beyzi, S. B., \& Kaliber, M. (2015). Effects of Dietary Supplementation of Dried Distillers Grain with Solubles (DDGS) and Yucca (Yucca schidigera) on Broiler Performance, Carcass Traits, Intestinal Viscosity and Marketing. 7. 
Schilling, M. W., Battula, V., Loar, R. E., Jackson, V., Kin, S., \& Corzo, A. (2010). Dietary inclusion level effects of distillers dried grains with solubles on broiler meat quality. Poultry Science, 89(4), 752-760. https://doi.org/10.3382/ps.2009-00385

Schone, R. A., Nunes, R. V., Frank, R., Eyng, C., Castilha, L. D., Schone, R. A., .. Castilha, L. D. (2017). Resíduo seco de destilaria com solúveis (DDGS) na alimentação de frangos de corte (22-42 dias). Revista Ciência Agronômica, 48(3), 548-557. https://doi.org/10.5935/1806-6690.20170064

Van Laack, R. L. J. M., Liu, C.-H., Smith, M. O., \& Loveday, H. D. (2000). Characteristics of Pale, Soft, Exudative Broiler Breast Meat. Poultry Science, 79(7), 1057-1061. https://doi.org/10.1093/ps/79.7.1057

Venturini, K. S., \& Sarcinelli, M. F. (2007). Chicken meat characteristics. Boletim Técnico PIE-UFES:01307, Pró-Reitoria de Extensão-Programa Institucional de Extensão, 7.

Welfare Quality, R. (2009). Welfare Quality R assessment protocol for poultry (broilers, laying hens). Welfare Quality R Consortium, Lelystad, Netherlands.

Whitehead, C. C., \& Bannister, D. W. (1981). Aspects of metabolism related to the occurrence of skin lesions in biotin-deficient chicks. British Poultry Science, 22(5), 467-472. https://doi.org/10.1080/00071688108447911

Wiltafsky, M., Fickler, J., Hess, V., Reimann, I., Zimmer, U., Reising, H., \& Heimbeck, W. (2010). AminoDat ${ }^{\circledR}$ 5.0, animal nutritionist's information edge. Evonik Nutrition \& Care, 3, 370 .

Youssef, I., Beineke, A., Rohn, K., \& Kamphues, J. (2010). Experimental study on effects of litter material and its quality on foot pad dermatitis in growing turkeys. Int. J. Poult. Sci, 9(12), 1125-1135. https://doi.org/10.3923/ijps.2010.1125.1135

Zanetti, M. A., Tedesco, D. C., Schneider, T., Teixeira, S. T. F., Daroit, L., Pilotto, F., ... Santos, L. R. dos. (2018). Economic losses associated with Wooden Breast and White Striping in broilers. Semina: Ciências Agrárias, 39(2), 887. https://doi.org/10.5433/1679-0359.2018v39n2p887

Zhang, Y., Shan, A., Jiang, W., Bi, C., \& Li, Z. (2013). The effect of vitamin E on growth performance and meat quality in broilers given diets containing distillers' dried grain with solubles (DDGS). British Poultry Science, 54(1), 138-143. https://doi.org/10.1080/00071668.2012.757578

\section{Copyright Disclaimer}

Copyright for this article is retained by the author(s), with first publication rights granted to the journal.

This is an open-access article distributed under the terms and conditions of the Creative Commons Attribution license (http://creativecommons.org/licenses/by/4.0/). 